Note

\section{Distribution of Dihydrofolate Reductase and Activity Producing Folate Cofactors in Rat Small Intestinal Segments}

\author{
Masahiro KoHASHI, Keizo YonedA \\ and Kazuo IwAI
}

Department of Food Science and Technology, Faculty of Agriculture, Kyoto University, Sakyo-ku, Kyoto 606, Japan

Received December 3, 1986

Conversion of pteroylglutamate (PteGlu) to 5methyltetrahydroPteGlu (5-methyl $\left.\mathrm{H}_{4} \mathrm{PteGlu}\right)$ involves reduction to tetrahydroPteGlu $\left(\mathrm{H}_{4} \mathrm{PteGlu}\right)$ by dihydrofolate reductase (DFR) and subsequent methylation to 5methylH ${ }_{4}$ PteGlu. ${ }^{1)}$ Olinger et al. ${ }^{2)}$ found greater conversion by rat jejunum when a physiological concentration of PteGlu (20 nM) is used, and minimal conversion and greater transfer to the portal vein of unchanged PteGlu when a high PteGlu concentration $(2 \mu \mathrm{M})$ is present. Recently, we have shown similar results in situ in rats using the loop method. ${ }^{3)}$

This paper describes the distribution of DFR activity, and the activity producing folate cofactors, $\mathrm{H}_{4} \mathrm{PteGlu}$ and 5-methylH $\mathrm{H}_{4}$ PteGlu, from PteGlu in the villi and total mucosal preparations of rat small intestine.

Male Wister rats $(240 \sim 260 \mathrm{~g})$ were anaesthetized with sodium pentobarbital $(55 \mathrm{mg} / \mathrm{kg})$. The removed small intestine was divided into three equal parts in length. They were referred to as upper, middle, and lower from the proximal to distal intestine. Each part was rinsed thoroughly with $0.9 \% \mathrm{NaCl}$ containing $1 \mathrm{~mm}$ dithiothreitol (DTT). The villi were prepared promptly by a modification of the procedure of Weiser ${ }^{4}$; the longitudinally incised small intestine was dipped for $15 \mathrm{~min}$ at $37^{\circ} \mathrm{C}$ into $100 \mathrm{ml}$ of büffer $\mathrm{A}, \mathrm{pH} 7.3$, containing $96 \mathrm{mM} \mathrm{NaCl}$, $27 \mathrm{~mm}$ sodium citrate, $8 \mathrm{mM} \mathrm{KH} \mathrm{KHO}_{4}, 5.6 \mathrm{~mm} \mathrm{Na} \mathrm{NPOO}_{4}$ and $1.5 \mathrm{~mm} \mathrm{KCl}$. After decantation of the solution, the residue was stirred at $120 \mathrm{rpm}$ for $30 \mathrm{~min}$ at $37^{\circ} \mathrm{C}$ in

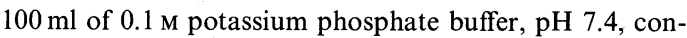
taining $0.9 \% \mathrm{NaCl}, 1.5 \mathrm{~mm}$ EDTA, and $0.5 \mathrm{~mm}$ DTT, and centrifuged at $900 \times g$ for $5 \mathrm{~min}$. The precipitate was washed 3 times with $0.1 \mathrm{M}$ potassium phosphate buffer, $\mathrm{pH} 7.4$ containing $0.9 \% \mathrm{NaCl}$ (PBS). This preparation is referred to as the villi preparation. The residual tissue was forcefully scraped to separate mucosa from the underlying smooth muscle layer and is referred to as the total mucosal preparation, which was washed
3 times with PBS. The villi and total mucosa of the upper, middle, and lower segments were individually suspended in $3 \mathrm{ml}$ of PBS, and homogenized with equal volumes of $0.1 \mathrm{~m}$ mannitol-1 mM Tris HEPES buffer, $\mathrm{pH}$ 7.4, at 20,000 rpm for $10 \mathrm{sec}$ using a Biomixer (Nihon Seiki Co., Ltd.). The homogenates were centrifuged at $32,000 \times g$ for $20 \mathrm{~min}$. The pellet and the supernatant fluid were divided into five equal samples and stored at $-20^{\circ} \mathrm{C}$ until used for the measurement of sucrase, ${ }^{5)} \gamma$-glutamyltransferase $(\gamma$-GTase $){ }^{6}{ }^{6}$ alkaline phosphatase (APase) ${ }^{7)}$ (for the pellet), and DFR activities ${ }^{8,9)}$ (for the supernatant), and protein content. ${ }^{10)}$ DFR activity was measured from the absorbance decrease at $340 \mathrm{~nm}$ for $10 \mathrm{~min}$ at $\mathrm{pH} 7.4{ }^{8}$ and $\mathrm{pH} 5.4 .^{9)}$ For the experiment with the activity producing folate cofactors from PteGlu, $0.5 \mathrm{ml}$ of the supernatant fluid obtained from the small intestinal segments was incubated for $1 \mathrm{hr}$ at room temperature with $0.2 \mathrm{ml}$ of $0.5 \mathrm{M}$ citrate buffer, $\mathrm{pH} 5.4$, and $1 \mathrm{ml}$ of hemoglobin-treated charcoal ${ }^{11)}$ to remove endogenous folate compounds, and centrifuged for $30 \mathrm{~min}$. The supernatant was concentrated with a Minicent-30 ultrafilter (Toyo Soda Co., Ltd.). The concentrate was used as the enzyme solution. The reaction mixture $(0.5 \mathrm{ml})$ consisted of $0.05 \mathrm{M}$ citrate buffer, $\mathrm{pH} 5.4,0.02 \mathrm{M}$ PteGlu, $0.1 \mathrm{~mm}$ NADPH, $20 \mathrm{~mm}$ 2-mercaptoethanol, and the enzyme solution (about $0.3 \mathrm{mg}$ protein). After incubation for $30 \mathrm{~min}$ or $3 \mathrm{hr}$ at $37^{\circ} \mathrm{C}, 350 \mu \mathrm{l}$ of methanol was added to $150 \mu \mathrm{l}$ of each reaction mixture and concentrated under $\mathrm{N}_{2}$ gas blowing. A sample $(25 \mu \mathrm{l})$ of the concentrate was used for analysing folate compounds by high-performance liquid chromatography with electrochemical detection (HPLCED). The HPLC-ED conditions were described previously, ${ }^{12)}$ except that we used a short column (4.6 i.d. $\times 50$ $\mathrm{mm}$ ) of Cosmosil $5 \mathrm{Ph}$.

Sucrase as an enzyme marker was used to verify the purity of the villi preparation as described by FortinMagana et al., who found more sucrase acicity in villi of the rat small intestine than in their crypt preparation. ${ }^{13}$ ) Measurement of sucrase activity in our preparations also indicated that the villi preparations from middle and lower contained mainly villi, not crypt. Greater specific activities of other membrane enzymes, $\gamma$-Gtase and APase, were also present in villi than in total mucosa.

DFR activity in the supernatant fluid of the rat small intestinal segments is shown in Table I. Unlike DFR of guinea pig intestine. ${ }^{14)}$ DFR of the rat small intestine reduced much more $\mathrm{H}_{2}$ PteGlu and PteGlu at $\mathrm{pH} 5.4$ than did at $\mathrm{pH}$ 7.4. The reduction rate of $\mathrm{H}_{2} \mathrm{PteGlu}$ at $\mathrm{pH} 5.4$ in the villi and total mucosal preparations of middle and lower, and the upper villi was greater than that in the upper total mucosa. DFR of villi preparations specifically reduced $\mathrm{H}_{2} \mathrm{PteGlu}$ at $\mathrm{pH}$ 5.4, although as well as $\mathrm{H}_{2}$ PteGlu. Table II shows the activity producing folate cofactors from PteGlu by the cell-free extracts of the rat small intestinal segments. The extracts of the upper and lower segments produced much more $\mathrm{H}_{4}$ PteGlu than 5-methylH ${ }_{4}$ PteGlu during $3 \mathrm{hr}$ of 
Table I. Dihydrofolate Reductase Activity in the Cell-Free Extracts of Rat SMall Intestinal Segments

\begin{tabular}{|c|c|c|c|c|c|}
\hline \multirow{2}{*}{\multicolumn{2}{|c|}{ Small intestine }} & \multirow{3}{*}{$\begin{array}{c}\begin{array}{c}\text { Total } \\
\text { protein } \\
\text { (mg) }\end{array} \\
31.9\end{array}$} & \multicolumn{3}{|c|}{ Reductase activity $^{a}$} \\
\hline & & & \multirow{2}{*}{$\frac{\mathrm{H}_{2} \text { PteGlu }(7.4)^{b}}{1.85}$} & \multirow{2}{*}{$\frac{\mathrm{H}_{2} \text { PteGlu }(5.4)^{b}}{3.26}$} & \multirow{2}{*}{$\frac{\text { PteGlu }(5.4)^{b}}{0.89}$} \\
\hline Upper & Villi & & & & \\
\hline & Total mucosa & 63.9 & 0 & 0.96 & 0 \\
\hline \multirow{2}{*}{ Middle } & Villi & 32.7 & 1.72 & 3.64 & 0.92 \\
\hline & Total mucosa & 72.9 & 2.67 & 3.89 & 1.68 \\
\hline \multirow[t]{2}{*}{ Lower } & Villi & 10.3 & 1.82 & 4.41 & 0 \\
\hline & Total mucosa & 73.5 & 2.64 & 3.87 & 3.49 \\
\hline
\end{tabular}

a DFR activity expressed as nmoles per min per mg protein at $37^{\circ} \mathrm{C}$ was measured in tissues from five rats.

$b$ Substrate and reaction $\mathrm{pH}$ in parenthesis.

Table II. Production of Tetrahydrofolate and 5-Methyltetrahydrofolate from Pteroylglutamic Acid by Rat Small Intestinal Segments

\begin{tabular}{|c|c|c|c|c|c|c|}
\hline \multirow{3}{*}{ Folate compound } & \multicolumn{6}{|c|}{ Amount of folate compound ${ }^{a}$} \\
\hline & \multicolumn{2}{|c|}{ Upper } & \multicolumn{2}{|c|}{ Middle } & \multicolumn{2}{|c|}{ Lower } \\
\hline & Villi & $\begin{array}{c}\text { Total } \\
\text { mucosa }\end{array}$ & Villi & $\begin{array}{c}\text { Total } \\
\text { mucosa }\end{array}$ & Villi & $\begin{array}{c}\text { Total } \\
\text { mucosa }\end{array}$ \\
\hline $\mathrm{H}_{4}$ PteGlu & $\begin{array}{c}16.0 \\
(33.4)\end{array}$ & $\begin{array}{c}72.2 \\
(48.4)\end{array}$ & $\begin{array}{c}0 \\
(24.0)\end{array}$ & $\begin{array}{c}5.8 \\
(5.0)\end{array}$ & $\begin{array}{c}72.0 \\
(85.8)\end{array}$ & $\begin{array}{c}8.0 \\
(7.0)\end{array}$ \\
\hline 5-Methyl $\mathrm{H}_{4}$ PteGlu & $\begin{array}{c}0 \\
(15.8)\end{array}$ & $\begin{array}{c}0 \\
(17.2)\end{array}$ & $\begin{array}{c}53.6 \\
(31.6)\end{array}$ & $\begin{array}{c}8.6 \\
(13.6)\end{array}$ & $\begin{array}{c}10.2 \\
(0.72)\end{array}$ & $\begin{array}{c}6.0 \\
(3.0)\end{array}$ \\
\hline
\end{tabular}

a Amounts of folate compounds produced by small intestinal segments (upper, middle and lower) are expressed as nmoles per mg protein per $30 \mathrm{~min}$ and $3 \mathrm{hr}$ (in parenthesis) at $\mathrm{pH} 5.4$.

incubation. Since the middle extracts produced much 5methyl $\mathrm{H}_{4}$ PteGlu and a small amount of $\mathrm{H}_{4}$ PteGlu in spite of the high DFR activity, the middle was shown to have a greater methylation activity than other intestinal segments. This shows a correlation between the location of DFR activity and the appearance of 5-methylH ${ }_{4} \mathrm{PteGlu}$ in the middle villi as reported by Olinger et al. ${ }^{2)}$ However, there was no correlation in the lower. These results suggest that various parts of rat small intestine can promptly reduce the luminal PteGlu to $\mathrm{H}_{4}$ PteGlu and 5methylH ${ }_{4}$ PteGlu.

\section{REFERENCES}

1) P. R. Nixon and J. R. Bertino, Am. J. Med., 48, 555 (1970).

2) E. J. Olinger, J. R. Bertino and H. J. Binder, J. Clin. Invest., 52, 2138 (1973).

3) M. Tani and K. Iwai, J. Chromatogr., 267, 175 (1983).
4) M. M. Weiser, J. Biol. Chem., 248, 2536 (1973).

5) A. Dalqvist, Anal. Biochem., 7, 18 (1964).

6) G. Szasz, "Methods of Enzymatic Analysis," Vol. 2, Verlag Chemie, Weinheim, 1974, pp. 715 720 .

7) E. Bernt, "Methods of Enzymatic Analysis," Vol. 2, Verlag Chemie, Weinheim, 1974, pp. 868 870.

8) B. T. Kaufman and R. C. Gardiner, J. Biol. Chem., 241, 1319 (1966).

9) W. Wilmanns, "Methods of Enzymatic Analysis," Vol. 2, Verlag Chemie, Weinheim, 1974, pp. $666 \sim 672$.

10) G. L. Miller, Anal. Chem., 31, 964 (1959).

11) N. Colman and V. Herbert, Blood, 48, 311 (1976).

12) M. Kohashi, K. Inoue, H. Sotobayashi and K. Iwai, J. Chromatogr., 382, 303 (1986).

13) R. Fortin-Magana, R. Huritz, J. J. Herbst and N. Kretchmer, Science, 167, 1627 (1970).

14) J. R. Bertino, A. T. Iannotti, J. P. Perkins and D. G. Johns, Biochem. Pharmacol., 15, 563 (1966). 